\title{
ACARDIACUS ANCEPS.
}

BY KEDARNATH DAS, M.D.,

Teacher of Midwifery and Gynæcology, Campbell Medical School, Calcutta.

\section{Origin and Development of Acardiaci.}

THE acardiaci or omphalosites might be logically included under the group of twin malformations. In all cases of double monostrosity there is, to begin with, one ovum the varieties in form and degree being determined by the extent and situation of the fission of the embryonal Anlage. When the splitting is complete and the two portions of the embryo go on to perfect development, there are born the so-called homologous or uniovular twins (Fig. I, A). While in their autositic stage they can hardly be called monsters, and would probably themselves resent that title, yet their mode of origin is doubtless the same in kind as that of true double monsters. The parasitic varieties of uniovular twins occupy the realm of real monsters. Up to the twelfth day both the embryos develop evenly. At that time the allantois buds out from the hind-gut of each individual, and its vessels reach the placental portion of the chorion. Sometimes the allantoic vessels, and later on the placental vessels, of the twins anastomose very freely. One foetus more vigorous may then overcome the force of the other's heart, which gradually ceases to act, so that the weaker foetus gradually dies (Fig. I, c). The increasing growth of the vigorous foetus compresses the dead one, and finally squeezes it flat against the uterine wall, so that the Fotus papyraceus results. When, however, anastomosis is not very free, and the inequality in the development of the two circulatory systems is not very marked, we have the condition which results in hydramnion (Fig. I, B). If the force of the one heart exceeds the other, its more powerful blood-stream usurps a portion of the placenta of the other twin also. Because of the unusual extent of the placental area, the heart of the stronger foetus undergoes further enlargement, and the renal secretion is thus augmented, causing an increase in the quantity of the liquor amnii of the stronger foetus. A time comes when the increasingly hypertrophied heart of the stronger fotus becomes incompetent. The result is congestion of the venous system, increased transudation into the amnion, and thus hydramnion.

In the case of true allantoic parasites, two healthy embryos develop from one ovum as in ordinary cases of homologous twins. The allantoic stalk of one may reach the inner surface of the primary 
chorion a few hours or so before that of the other. It becomes attached to the chorion here, and begins to develop its umbilical vessels before the second allantois reaches the placental site. Therefore the allantois of the second embryo finds no chorionic attachment, or only a limited one, and is compelled to attach itself to the allantois of the first. There results an anastomosis of the umbilical vessels, and the first foetus becomes dominant in the circulation. As the allantoic stalks become lengthened out into umbilical cords, the cord of the second may be attached to that of the first, at some distance from the placenta. It may be attached to the placenta close to that of the first, or the two may be connected by a large vessel upon the placenta. The anastomosing arteries will carry all, or nearly all, of the blood directly from the circulatory system of the first, without going through the placenta, into that of the second. The venous current, being slower, will not follow the line of least resistance so markedly. The second embryo thus gets arterial (i.e., vitiated) blood from the first embryo's body. The pressure of blood from the heart of the first forces the current backward through the arteries of the second. The heart of the latter atrophies. The current is more direct from the umbilical arteries towards the lower part of the foetus by way of the hypogastric arteries than towards the head. In fact, the hypogastric arteries become the important vessels of the parasitic foetus. The organs normally receiving blood direct from the heart, such as lungs, head, liver, etc., become atrophied, or fail to develop at all. The distance from the heart of the autosite, which is the only pumping force in both fotuses, is so great that the circulation is weak in the parasite's vascular system. On account of the stasis in the veins there are usually hypertrophy of the connective tissue, especially of the skin, and general œdema of the subcutaneous cellular tissues (Fig. I, D and E).

\section{Classification.}

According to the degree of the development of the allantois and placenta of the second embryo, we get several varieties in acardiac foetuses :

I. Acardiacus anceps is the least atrophied form, characterized by absence or non-development of face, the extreme anterior part of the body. There are rudiments of cranial bones and of the brain. It has more or less perfect trunk and extremities. It presents the transition to well-developed twins from one ovum. The species is rare. 


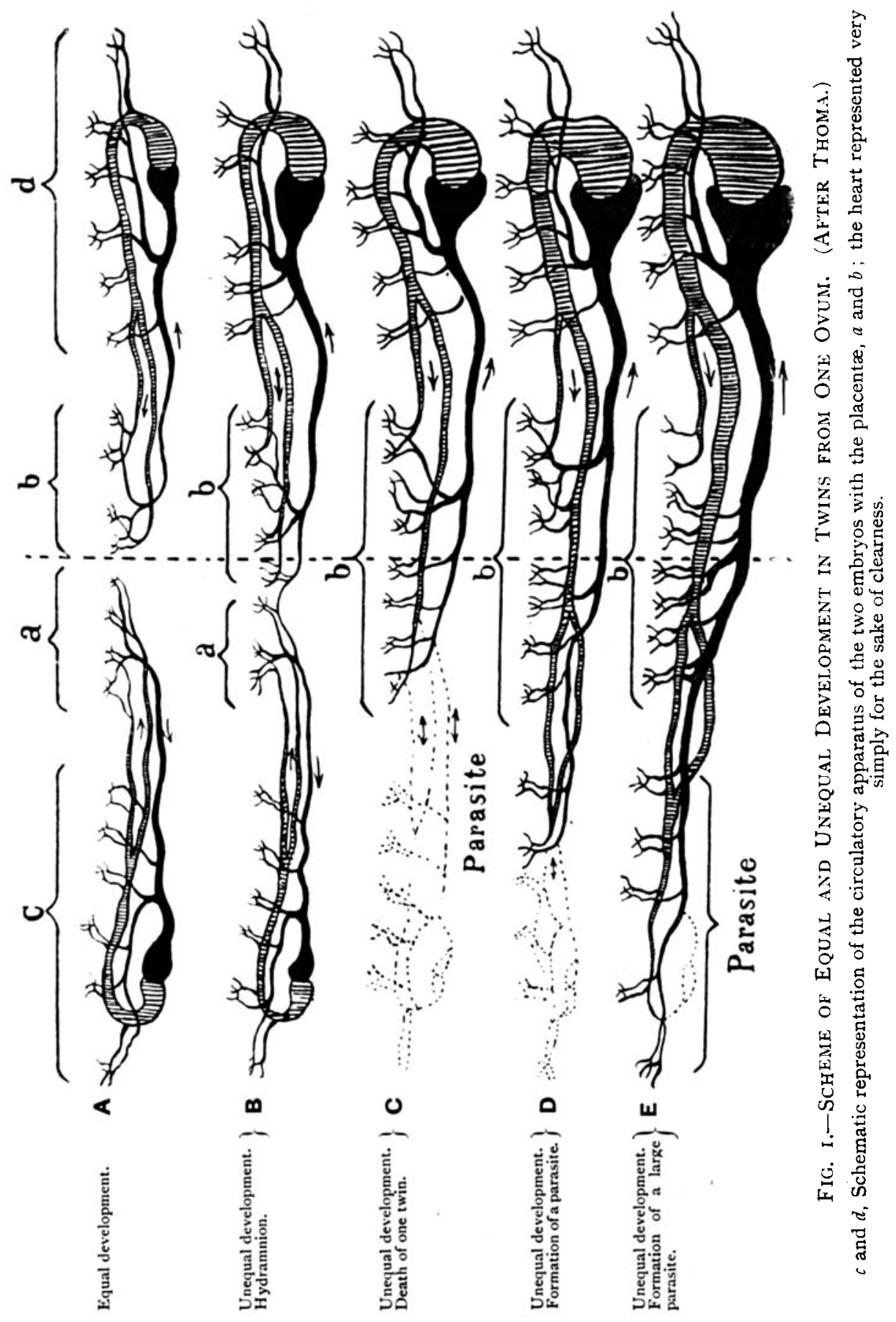




\section{Journal of Obstetrics and Gynæcology}

2. A. acephains is the most common species. Head wanting, or very rudimentary. Intestines and abdominal organs rudimentary, and the organs above the diaphragm represented by the merest trace. Rarely more than a few vertebræ present, and these are usually of the lumbar or sacral type. Shoulder girdle undeveloped. Pelvis and lower extremities more nearly perfect.

3. A. amorphus. - Least developed. Little more than a lump of connective tissue, covered by œematous skin. Sometimes a tract of hairy scalp is seen. Usually some attempt at budding out of limbs, though seldom with any systematic bony structure. There may be some rudiments of visceral tissue.

4. A. acormus.-Rarest. Head alone present, but never fully developed.

\section{Clinical History of a Case under the Author's Observation.}

The following is the clinical history of a patient from whom I was fortunate enough to secure a specimen of acardiacus anceps. A healthy Bengali lady, aged twenty-one, 5-para, o abortions, consulted Dr. S. N. Sen on May I4, I90I, for dyspnoea and palpitation. Her menstruation had ceased six months ago, and she had all the symptoms of pregnancy. At the end of the fourth month the abdomen began to increase in size rather rapidly, and at the end of the sixth month it was so big as to cause marked distress from pressure. When first seen by Dr. Sen, to whom I am indebted for the history of the case, the following conditions were noted: 'Uterus rather bigger than even at full-term pregnancy. Fotal movements present. No fotal heart sounds detected. Legs and feet œdematous. Pulse frequent. Respiration hurried.' On May I5 pains commenced. Dyspncea and palpitation worse. Fotal movements still felt. On the I6th pains continued irregular and ineffectual. No dilatation of the os uteri. No fœtal movements perceived from the evening. On the morning of the I 7 th os dilated about three fingers' breadth. Pains irregular and inefficient. Presentation could not be made out; only the tense bag of membranes felt. Patient was getting exhausted. The membranes were ruptured by the midwife in attendance, and a very large quantity of liquor amnii escaped. Both feet of a foetus presented. I saw the patient at this stage. The presenting legs were blue, tense and odematous. On gentle traction, the lower extremities of the foetus, with the pelvis, gave way. The patient was at once put under chloroform and the uterus explored. The trunk of fortus was delivered by hooking it with a finger, pushed 
Kedarnath Das: Acardiacus Anceps

345

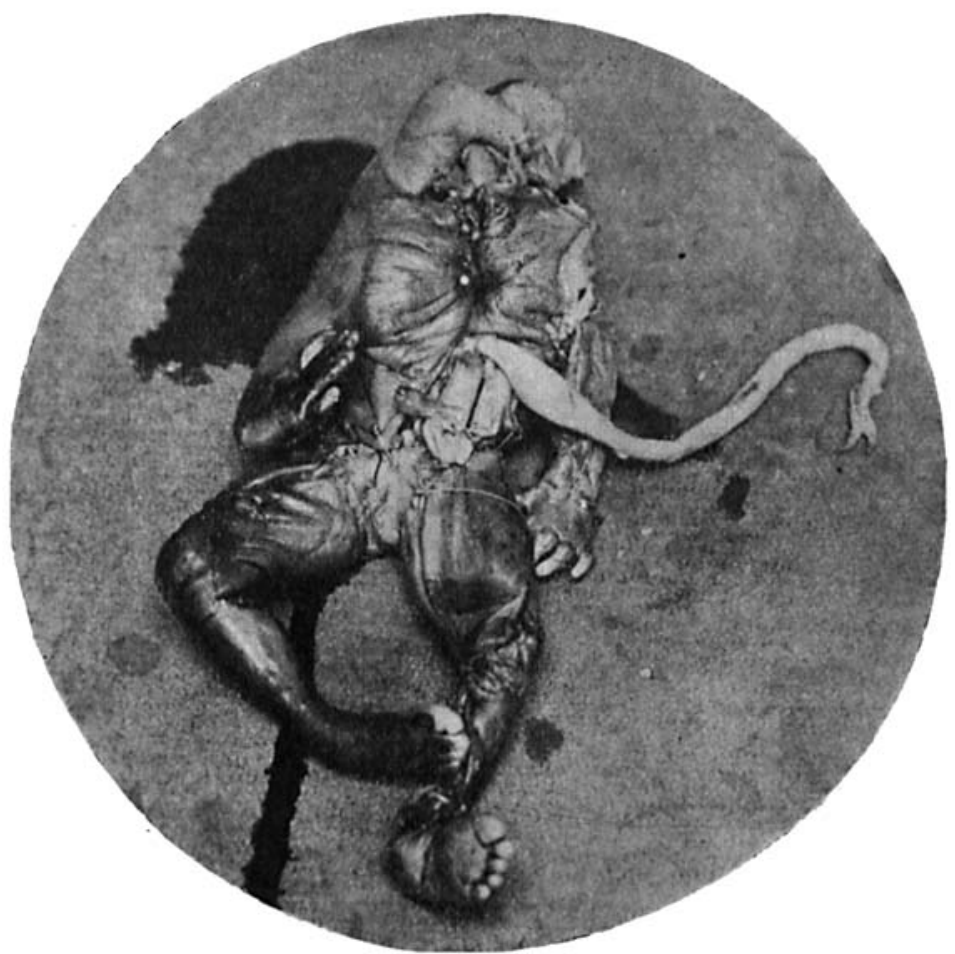

FIG. 2.

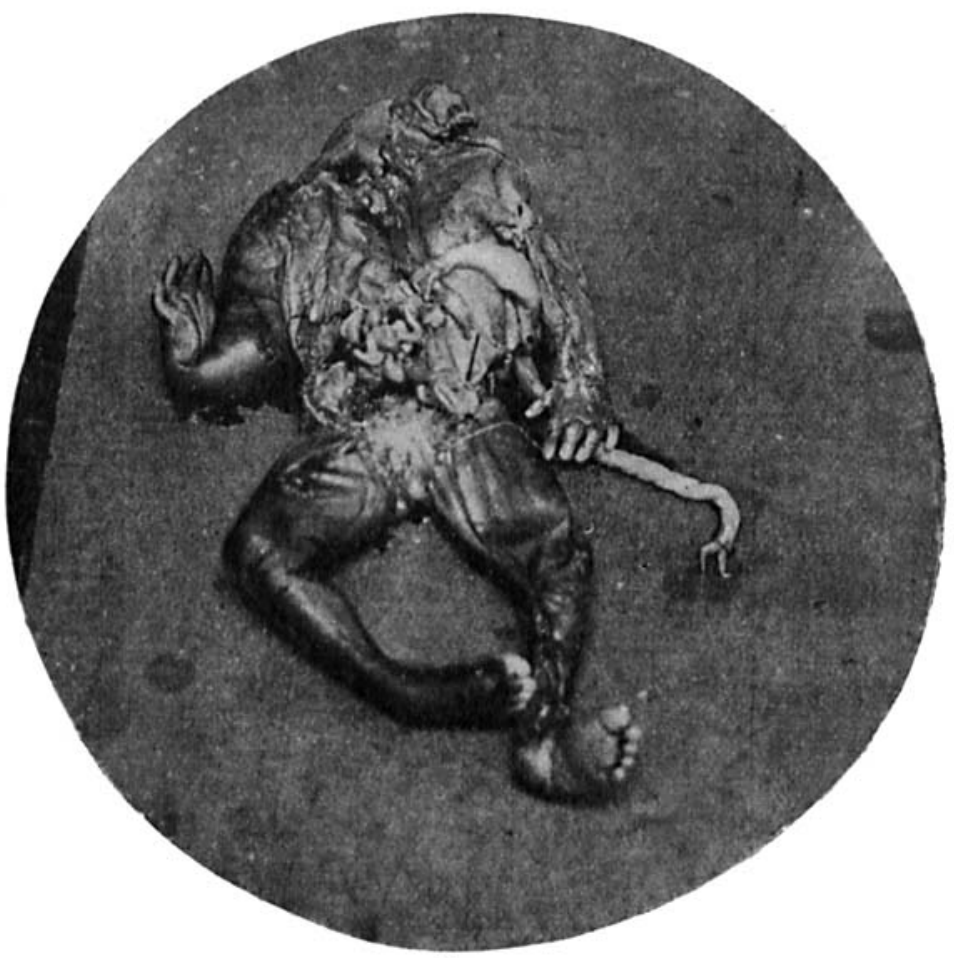

Fig. 3 . 


\section{Journal of Obstetrics and Gynæcology}

in easily through the tense odematous skin. The finger felt as though passing through the pulp of a water-melon. No head was found. On putting my hand in the uterus again, another foetus was detected and brought away. This was perfectly formed. The single placenta came out shortly afterwards. The subsequent progress was satisfactory.

\section{Description of the Monster.}

The torn parts of the monster were stitched up and photographed the next day, after being in formalin solution for more than twentyfour hours. Fig. 2 shows the monster stitched up, and Fig. 3 shows the abdominal and the potential thoracic cavity exposed by an anterior median incision.

External Appearances. -The monster measured $20^{\circ} 5 \mathrm{~cm}$. from end to end. It was dark blue in colour, and markedly œedematous about the trunk. There was no indication of a head and face. Anteriorly there was a distinct crypt about $2 \mathrm{~cm}$. below the cephalic end of the specimen. The crypt contained six tiny tubercles, three on either side, and some fine hair. These tubercles apparently indicated the fronto-nasal process, the maxillary process, and the mandible. The umbilical cord was attached about $4 \mathrm{~cm}$. below the crypt. Penis and scrotum well developed. Right upper extremity 'trunk-hosed.' Breadth of the upper arm at axilla, $3 \mathrm{~cm}$.; at the wrist, $\mathrm{I} \mathrm{cm}$. Right hand attached to forearm at a very acute angle. No thumb on right hand. Left arm comparatively slender, the hand containing five fingers, but the thumb diminutive. Lower extremities well developed, double talipes varus. Trunk: A median incision was made from below the crypt to the symphysis pubis. There was a fairly developed diaphragm separating the abdominal from the potential thoracic cavity. There was no true thoracic cavity, but the space between the ribs and diaphragm was occupied by loose embryonic tissue. No indication of lungs, osophagus, etc. The abdomen contained some coils of small intestines. The rectum was fairly developed, and ended in a patent anus. No liver, spleen, or pancreas. Two lobulated kidneys. Bladder could not be distinctly made out, owing to the mutilation about its site. Two vessels, evidently the afferent and the efferent, could be traced from the umbilical cord. Immediately underneath the umbilicus, and attached to the umbilical cord for about $2.5 \mathrm{~cm}$. by a thin band of fibrous tissue, was a small solid spindle-shaped muscular-looking tissue (? heart), about $5 \mathrm{~mm}$. long and $3 \mathrm{~mm}$. broad. The other end also had a thin fibrous cord, which was torn from its distal attachment. On making a transverse 
section through this muscular spindle, a $T$-shaped slit could be made out, but no distinct cavity. Osseous system well developed, except the cranium. A very marked bend in the spinal column about the upper dorsal region. All the vertebræ and ribs present. The acromial ends of the clavicles touched each other in the middle line; the clavicles thus lay vertical and parallel to each other. The sternum was represented by a small piece of cartilage attached to the sternal ends of the clavicles. All the ribs tended towards this cartilage. What might be called the undeveloped cranium was attached to the cephalic end of the spinal column. It was $2 \mathrm{~cm}$. long and ${ }^{\circ} 5 \mathrm{~cm}$. broad, lined by dura mater. It had six distinct bones, representing, apparently, the supra-occipital and the basi-occipital in the middle, with two parietals and two temporals (squamosal and periotic) on each side. No other bones of the face or head were represented. The six tubercles above referred to were attached to a membrane connecting the parietals, temporals and the basi-occipital on the anterior aspect of this undeveloped cranium. It will thus be seen that development was arrested at the cephalic extremity of the monster. The structures derived from all the visceral arches were absent. The specimen thus clearly belonged to that very rare variety of acardiacus, the Acardiacus anceps. As far as I have been able to ascertain, this is the only specimen of acardiac monster in India.

\section{A Review of Cases from Literature.}

I append below a list of acardiac monsters from literature. Some kind of description was given in the first twenty-eight cases. In some of these a brief history of the mother was given too. Nos. 29 to 32 were merely mentioned. There were diagrams of the remaining thirteen cases. The tabulated cases might be reviewed under the following headings :

I. Parity.-Acardiacs are said to be rarely born in first labours (Geoffroy St. Hilaire). But of Io cases in which the number of the pregnancy was noted 5 were primiparæ. So it is far from rare in first labours.

2. Duration of pregnancy was noted in II cases; in 6 it reached to full term.

3. Birth of the Monster.-The perfect twin is generally said to be born first. In 9 out of II cases the healthy twin was born first. Presentation was noted in 6 cases -2 by feet, 2 breech, and 2 cephalic end.

4. Sex of the Monster.-The sexes of the twins are identical. Dr. Dickinson's case, No. 14 in the list, is a doubtful exception. 
TABLE OF ACARDIACI

(For Original Reports, see Corresponding

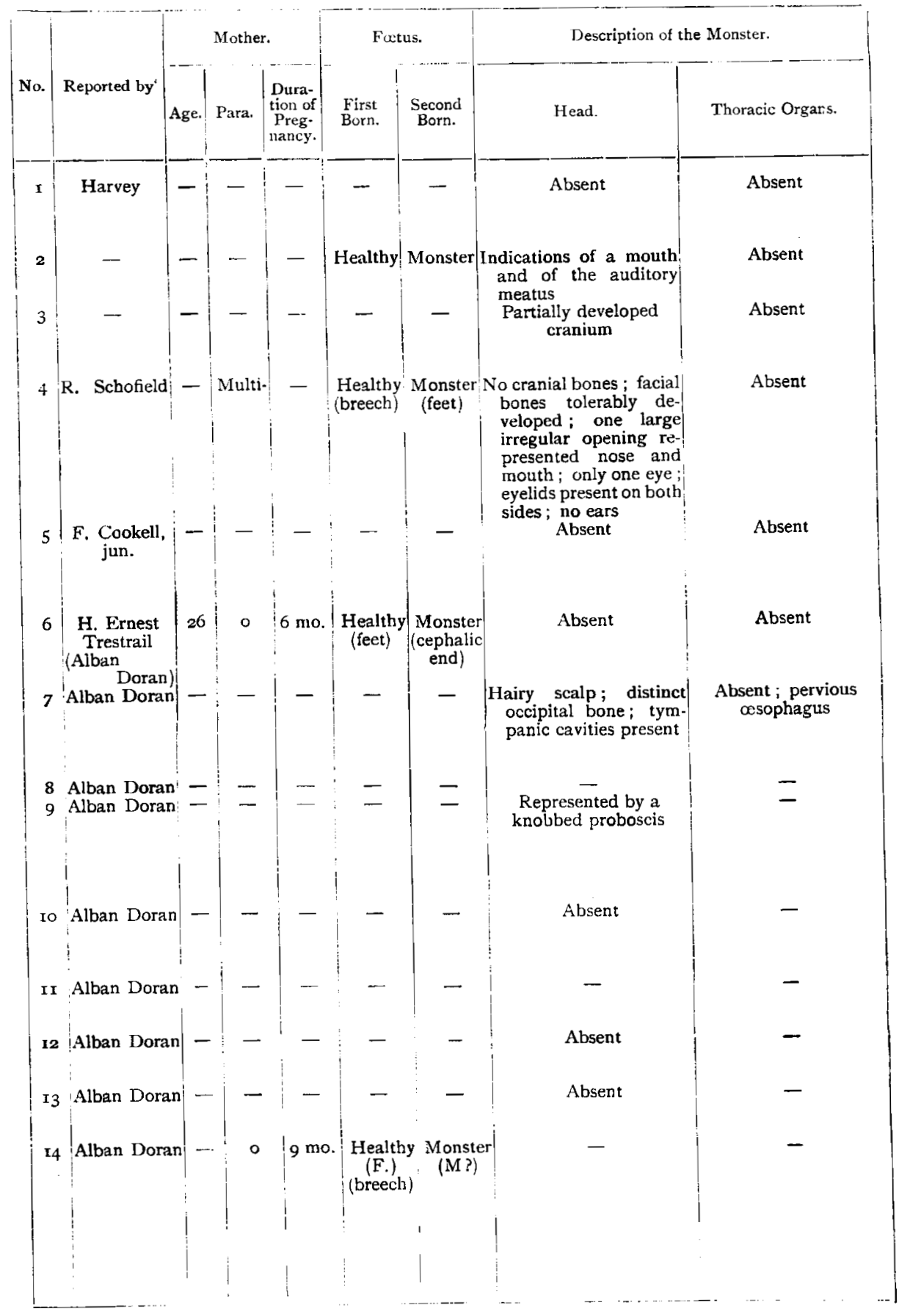


FROM LITERATURE.

Numbers in List of References.)

\begin{tabular}{|c|c|c|c|c|c|}
\hline \multirow[b]{2}{*}{ Aludominal Organs. } & \multicolumn{4}{|c|}{ Description of the Monster-Continued. } & \multirow[b]{2}{*}{ Remarks. } \\
\hline & $\begin{array}{l}\text { Upper } \\
\text { Extremities. }\end{array}$ & $\begin{array}{l}\text { Lower } \\
\text { Extremities. }\end{array}$ & $\begin{array}{l}\text { Genito-Urinary } \\
\text { Organs. }\end{array}$ & Classification. & \\
\hline $\begin{array}{l}\text { Intestines rudimen- } \\
\text { tary } ; \text { anus patent } \\
\text { no other organs }\end{array}$ & Absent & $\begin{array}{l}\text { Large and well } \\
\text { formed; varus. } \\
\mathrm{L} .=3 \text { toes ; R. }\end{array}$ & $\begin{array}{c}\text { External organs well } \\
\text { marked }(\mathrm{F} .) \text {; no } \\
\text { internal genera- } \\
\text { tive }\end{array}$ & Acephalus & $\begin{array}{l}\text { ? Two } \\
\text { placentat }\end{array}$ \\
\hline $\begin{array}{l}\text { Intestines rudimen- } \\
\text { tary: no other } \\
\text { organs }\end{array}$ & Absent & $\begin{array}{c}\text { Two wartlike pro- } \\
\text { jections }\end{array}$ & $\begin{array}{l}\text { tuve organs } \\
\text { A rudimentary } \\
\text { kidney }\end{array}$ & Acephalus & - \\
\hline $\begin{array}{l}\text { Intestines rudimen- } \\
\text { tary; (?) liver } \\
\text { represented by a }\end{array}$ & $\begin{array}{l}\text { One projection } \\
\text { only }\end{array}$ & $\begin{array}{l}\text { One projection } \\
\text { only }\end{array}$ & Bladder : ovaries & Acephalus & - \\
\hline - & Absent & $\begin{array}{l}\text { Imperfectly de- } \\
\text { veloped and } \\
\text { œd e ma tous } \\
\text { two toes in one, } \\
\text { three in the } \\
\text { other }\end{array}$ & $\begin{array}{l}\text { No external } \\
\text { genitals }\end{array}$ & Acephalus & $\begin{array}{l}\text { Delivery } \\
\text { difficult }\end{array}$ \\
\hline $\begin{array}{l}\text { No depression to } \\
\text { indicate anus }\end{array}$ & $\begin{array}{c}\text { R. represented } \\
\text { by a short } \\
\text { d ig i t, L. b y } \\
\text { a thumb and }\end{array}$ & $\begin{array}{l}\text { Fairly developed } \\
\text { very cedema- } \\
\text { tous ; varus } \\
\text { toes deficient }\end{array}$ & $\begin{array}{c}\text { Penis of fair size } \\
\text { no testicles }\end{array}$ & Acephalus & - \\
\hline $\begin{array}{l}\text { Intestines rudimen- } \\
\text { tary; no upper } \\
\text { abdominal viscera }\end{array}$ & $\begin{array}{l}\text { little finger } \\
\text { Absent }\end{array}$ & $\begin{array}{l}\text { L. fairly de- } \\
\text { veloped; four } \\
\text { toes; varus. }\end{array}$ & $\begin{array}{l}\text { One kidney; clitoris; } \\
\text { no bladder, uterus } \\
\text { or ovaries }\end{array}$ & $\begin{array}{l}\text { Acephalus } \\
\text { (monopus) }\end{array}$ & $\begin{array}{c}\text { Hydramnion, } \\
\text { Mus. R.C.S. I5 }\end{array}$ \\
\hline $\begin{array}{l}\text { Stomach blind at } \\
\text { pylorus; } \frac{1}{4} \text { in. } \\
\text { small intestine; a } \\
\text { large intestine } \\
\text { pervious at anus }\end{array}$ & Absent & $\begin{array}{l}\text { R. absent } \\
\text { Imperfect } L .\end{array}$ & $\begin{array}{l}\text { Horseshoe kidney; } \\
\text { bladder; sex not } \\
\text { indica ted ; L. } \\
\text { Wolffian body } \\
\text { hypertrophied }\end{array}$ & Acephalus & $\begin{array}{l}\text { My lacepha- } \\
\text { lus (Doran). } \\
\text { R.C.S., 8, } 9\end{array}$ \\
\hline - & L. rudimentary & Better formed & Male & Acephalus & R.C.S., 12 \\
\hline $\begin{array}{l}\text { In test in es com- } \\
\text { menced as a blind, } \\
\text { sac in the cord, } \\
\text { and terminated in } \\
\text { animpervious rec- } \\
\text { tum ; no liver }\end{array}$ & $\begin{array}{l}\text { R.ill-developed, } \\
\text { ended in a } \\
\text { single nail. } \\
\text { L. absent }\end{array}$ & $\begin{array}{c}\text { Present. R. three } \\
\text { toes }\end{array}$ & $\begin{array}{l}\text { Generative organs } \\
\text { too imperfect to } \\
\text { denotesex; horse- } \\
\text { shoe kidney, two } \\
\text { ureters, and a } \\
\text { bladder }\end{array}$ & Acephalus & R.C.S., I3, I4 \\
\hline $\begin{array}{c}\text { A small portion of } \\
\text { intestines only }\end{array}$ & Absent & $\begin{array}{c}\text { L a r g e, m a l- } \\
\text { formed; 'trunk- } \\
\text { hosed '; defec- } \\
\text { tive toes; varus }\end{array}$ & $\begin{array}{c}\text { Penis and scrotum } \\
\text { well developed }\end{array}$ & Acephalus & $\begin{array}{l}\text { St. Bart. 's, } \\
3,435\end{array}$ \\
\hline- & L. phocome- & Fairly formed ; & $\begin{array}{c}\text { Vulvar aperture } \\
\text { distinct }\end{array}$ & Acephalus & $\begin{array}{l}\text { St. Bart.'s, } \\
3,435^{\mathrm{A}}\end{array}$ \\
\hline- & $\begin{array}{r}\text { detective } \\
\text { Absent }\end{array}$ & $\left\{\begin{array}{l}\text { Fairly developed ; } \\
\text { varus : R. toes } \\
\text { imperfect }\end{array}\right.$ & $\begin{array}{c}\text { Male organs well } \\
\text { formed }\end{array}$ & Acephalus & $\begin{array}{l}\text { St. Thomas's, } \\
\text { LL. } 2 \text { I }\end{array}$ \\
\hline - & Absent & $\begin{array}{l}\text { Trunk - hosed ; } \\
\text { varus ; three } \\
\text { toes }\end{array}$ & F. & Acephalus & $\begin{array}{l}\text { St, Thornas's, } \\
\text { LL. } 2 \mathbf{I}^{\mathrm{I}}\end{array}$ \\
\hline- & $\begin{array}{c}\text { Arms fairly de } \\
\text { veloped }\end{array}$ & $\begin{array}{c}\text { Legs and feet } \\
\text { large }\end{array}$ & $\begin{array}{l}\text { Male ; external or- } \\
\text { gans well formed } \\
\text { (but see Trans. } \\
\text { Obstet. Soc. Lon- } \\
\text { don, vol. xxxi., } \\
\text { I889, p. 23.) }\end{array}$ & Acephalus & $\begin{array}{l}\text { St. George's, } \\
\text { 17DiDr.Dick } \\
\text { inson's case; } \\
M \text { ed ico } \\
\text { Chirurgical } \\
\text { Transac } \\
\text { tions, xlvi. } \\
\text { I4I, I } 863\end{array}$ \\
\hline
\end{tabular}


TABLE OF ACARDIACI

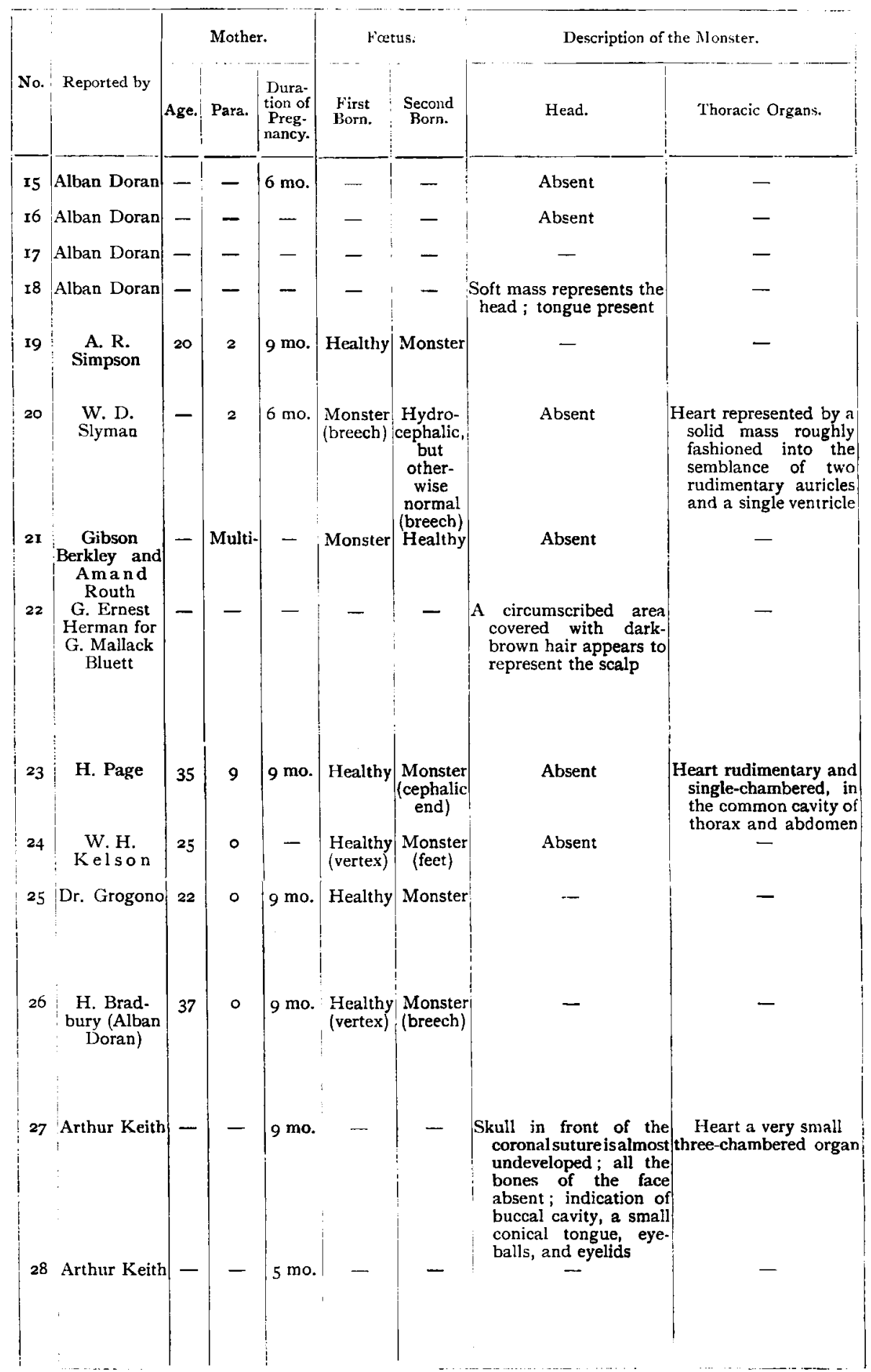


FROM LITERATURE-Continued.

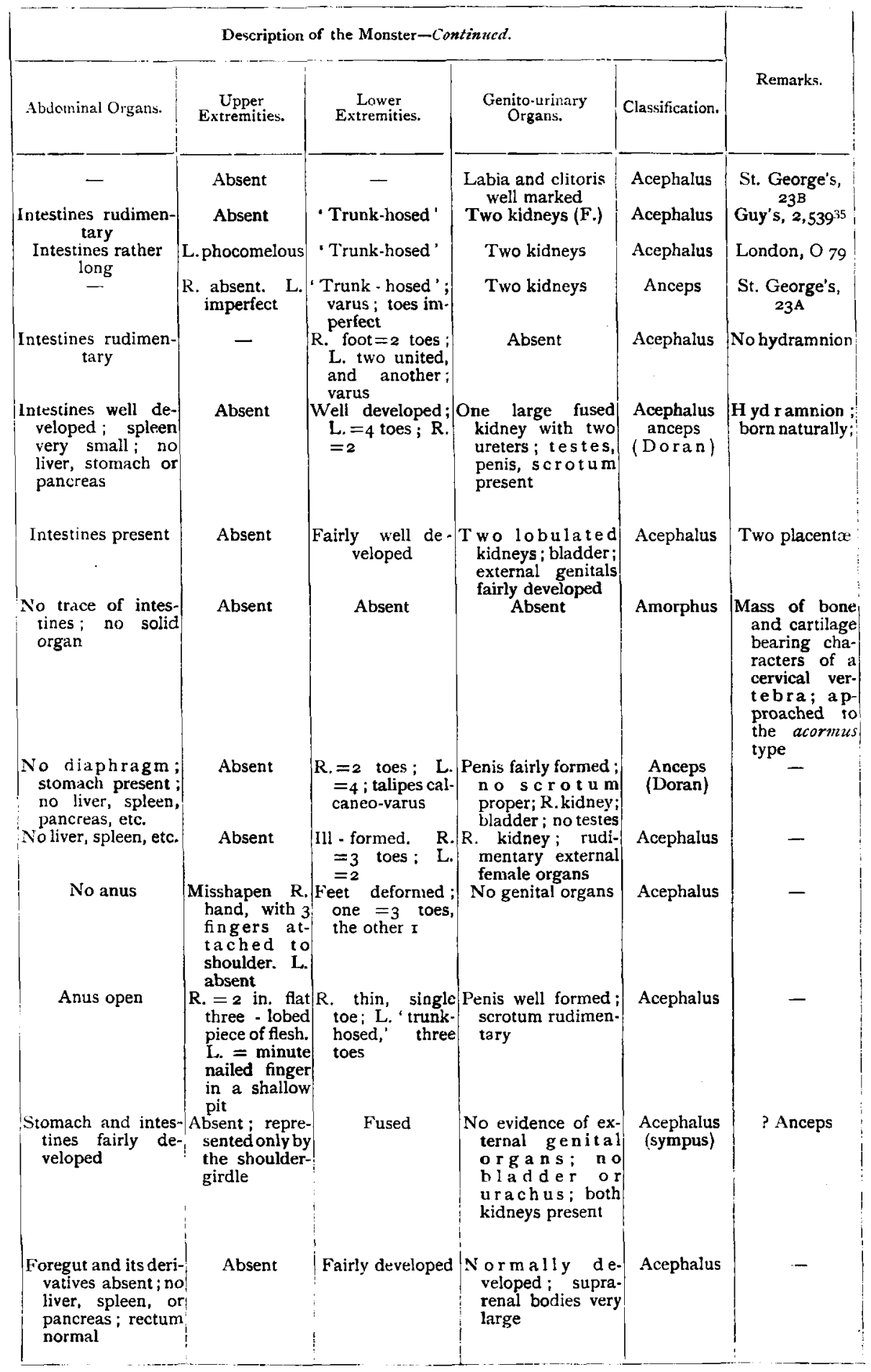


TABLE OF ACARDIACI

\begin{tabular}{|c|c|c|c|c|c|c|c|c|}
\hline \multirow[b]{2}{*}{ No.: } & \multirow[b]{2}{*}{ Reported by } & \multicolumn{3}{|c|}{ Mother. } & \multicolumn{2}{|c|}{ Fœtus. } & \multicolumn{2}{|c|}{ Description of the Monster. } \\
\hline & & Age: & Para. & $\begin{array}{l}\text { Dura- } \\
\text { tion of } \\
\text { Preg. } \\
\text { nancy. }\end{array}$ & $\begin{array}{l}\text { First } \\
\text { Born. }\end{array}$ & $\begin{array}{l}\text { Second } \\
\text { Born. }\end{array}$ & Head. & Thoracic Organs. \\
\hline $\begin{array}{l}29 \\
30\end{array}$ & $\begin{array}{l}\text { Alban Doran } \\
\text { M. IIand- }\end{array}$ & $=$ & 二 & $5 \overline{\mathrm{mo}}$ & $=$ & - & z & z \\
\hline $3 \mathrm{I}$ & $\begin{array}{l}\text { Sir James } \\
\text { Simpson }\end{array}$ & - & - & - & - & - & - & - \\
\hline 32 & $\begin{array}{l}\text { A. R. } \\
\text { Simpson }\end{array}$ & - & - & - & - & - & - & - \\
\hline 33 & $\begin{array}{l}\text { Lusk } \\
\text { Veendam }\end{array}$ & - & - & - & - & - & - & - \\
\hline 35 & $\begin{array}{l}\text { Veendam } \\
\text { Charpentier }\end{array}$ & $\overline{-}$ & $\overline{-}$ & 二 & 二 & $\bar{z}$ & 二 & $\bar{Z}$ \\
\hline & Poppel & - & - & - & - & - & - & - \\
\hline 37 & $\begin{array}{l}\text { Reisman and } \\
\text { Hektoen }\end{array}$ & - & - & - & - & - & - & - \\
\hline $3^{8}$ & Barkow & - & - & - & - & - & - & - \\
\hline 39 & $\begin{array}{l}\text { Ahlifeld } \\
\text { Ahleld }\end{array}$ & $=$ & E & - & - & - & $\bar{z}$ & - \\
\hline 41 & Hirst and & - & - & - & - & - & - & - \\
\hline 42 & Hirst and & - & - & - & - & - & - & - \\
\hline & $\begin{array}{l}\text { Piersol } \\
\text { Ahlfeld }\end{array}$ & - & - & - & 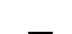 & & & - \\
\hline 43 & Thoma & - & - & - & - & 二 & 二 & 二 \\
\hline 45 & Thoma & - & - & - & - & - & - & - \\
\hline
\end{tabular}

5. Hydramnion is said to be usually present. The quantity of liquor amnii is noted in 3 cases only, in 2 of which it was abundant.

6. Character of labour is noted in only two cases, one difficult and the other natural. That dystocia may be caused by hydramnios and the peculiar conformation of the monster is evident from my case. Spiegelberg draws special attention to this point.

7. Classification.-All forms of acardiacs can be classed under one or other of the four varieties above referred to. Alban Doran thinks that a fifth variety- $A$. mylacephalus-conveniently includes certain cases. Case No. 6 in the list, which Doran at first classified under mylacephalus, has been grouped by him later on under $A$. acephalus (var. monopus). No. 7 in the list might similarly be included under $A$. acephalus. The classification would thus be a little simplified. Of the 45 cases, 37 were Acephalus, 3 Acormus, 2 Amorphus, and 3 Anceps. The classification of some of the cases might be reconsidered.

\section{Teratogenesis.}

Finally, a few remarks might be made with regard to the causation of monstrosities. The theory of the influence of maternal impressions causing malformations is quite untenable. Almost all the typical varieties of monsters have been produced experimentally 
FROM LITERATURE-Continued.

\begin{tabular}{|c|c|c|c|c|c|}
\hline \multirow[b]{2}{*}{ Abdominal Organs. } & \multicolumn{3}{|c|}{ Description of the Monster-Continued. } & & \multirow[b]{2}{*}{ Remarks. } \\
\hline & $\underset{\text { Extremer }}{\text { Upties. }}$ & $\begin{array}{c}\text { Lower } \\
\text { Extremities. }\end{array}$ & $\begin{array}{l}\text { Genito-Urinary } \\
\text { Organs. }\end{array}$ & Classification. & \\
\hline - & $\overline{-}$ & - & $=$ & $\begin{array}{l}\text { Acephalus } \\
\text { Acephalus }\end{array}$ & Guy's, 2,539+o \\
\hline- & - & - & - & Acephalus & $\begin{array}{l}\text { Only men- } \\
\text { tioned. }\end{array}$ \\
\hline- & - & - & - & Acephalus & \\
\hline- & - & - & - & Acephalus & \\
\hline - & $=$ & $\ddot{-}$ & - & Acephalus & \\
\hline - & - & $=$ & $\overline{-}$ & Acephalus & \\
\hline- & - & - & - & Acephalus & \\
\hline- & - & - & - & Acormus & \\
\hline 二 & - & $\overline{-}$ & - & $\begin{array}{l}\text { Acormus } \\
\text { Acormus }\end{array}$ & Only \\
\hline- & - & - & - & $\begin{array}{l}\text { Acormus } \\
\text { Acephalus }\end{array}$ & \\
\hline- & - & - & - & Acephalus & \\
\hline- & - & - & - & Amorphus & \\
\hline - & $\overline{-}$ & - & $\overline{-}$ & $\begin{array}{c}\text { Acephalus } \\
\text { Anceps }\end{array}$ & \\
\hline
\end{tabular}

upon the eggs of birds and lower animals by the action of physical forces external to the embryo. For those still undetermined there is reason to believe that a rational cause will at some time be found. Mechanical hindrances-amniotic bands or adhesions-frequently arrest development, causing fotal anomalies. Fission of the embryo is possible from mechanical force. O. Schultze produced double monsters by holding eggs between glass plates, and turning them at different angles during segmentation stage. Fish-eggs carried far in railroad cars and other vehicles, and therefore subjected to considerable shaking, show a much greater percentage of double formation than eggs hatched without such agitation. In mammals the splitting of the embryo is probably very often due to constriction of the zona pellucida. It may thus be seen that external conditions acting on the fotus in utero, and internal conditions, inherent or induced in the foetus itself, cause these malformations. In the small and delicate structures which form the early embryo, very slight and simple disturbances may interfere with the completion of parts. Thus, the influence of a blow on the abdomen, a fall or a violent movement, might extend through the uterine wall to the developing embryo. Arthur Keith suggests that inquiry into the condition of the mother during the weeks following conception might throw some light on the cause. But the patient will seldom take notice of trivial accidents 
at such an early period, when she is as yet ignorant of the existence of pregnancy. I inquired very carefully about any abnormal condition in the early pregnancy in my case, and could get no information, as the patient failed to remember anything.

\section{Specimen in the Madras Medical College.}

Since writing the above, I have been favoured by LieutenantColonel Sturmer, I.M.S., of Madras, with the particulars of a case of acardiac monster which is in the museum of the Madras Medical College. The specimen was found by Colonel Branfoot some years ago. It was one of a twin female birth, the other child was born alive and normally formed. There was a small tuft of hair and ill-developed bone in the centre of the mass, just above the point of entrance of the umbilical vessels. Below this was a small abdominal cavity, and above it the foetal mass consisted of three cavities filled with serous fluid, and lined by a smooth membrane. A very curved and partially developed spinal column was found leading backwards and downwards from the position of the hairy tuft. There was no trace of heart, lungs, or brain; the abdominal organs were imperfectly developed. The lower limbs consisted mainly of a mass of low œdematous tissue. It was apparently of the acephalous variety. This, then, is the second specimen in India.

\section{REFERENCES}

The Numbers refer to the Cases in the Tables.

- Lancet, I848, vol. ii., p. 696.

2 British and Foreign Medico-Chirurgical Review, I860, vol. ii., p. 543.

3 British Medical Journat, i879, vol. ii., p. 303 .

4 Trans. Obstet. Soc. Lond., vol. xxi., I879, p. 7 I.

5 Ibid., vol. xxv., I883, p. I10.

6 to 18 Ibid., vol. xxxi., 1889 , pp. 2-27.

19 'Contributions to Obstetrics and Gynæcology,' A. R. Simpson, I880.

20 Trans. Obstet. Soc. Lond,, vol. xxxi., I889, p. 258.

${ }^{21}$ Ibid., vol. xxxii., 1890, p. 347.

22 Ibid., vol. xxxiv., I892, p. I I.

23 to 24 Ibid., vol. xxxiii., 1891, pp. 195, 302.

25 Ibid., vol. xxxvi., I894, p. I85.

26 Ibid., vol. xxxvii., 1895, p. 209.

27 to 28 Ibid., vol. xlii, 1900, p. 99.

29 Ibid., vol. xxxi., I889, p. 24.

30 Ibid., vol. xxxiv.. I892, p. 84 .

$3^{1}$ to 32 'Contributions to Obstetrics and Gynacology,' A. R. Simpsor, i 880.

33 LUSK: 'Science and Art of Midwifery,' 4th edition, p. 558.

34 HiRst and MANN : 'System of Obstetrics and Gynæcology by American Authors,' vol. i., p. 299. 


\section{Kedarnath Das: Acardiacus Anceps}

3.5 to $3^{6}$ CHARPEnTIER : 'Obstetrics,' vol. iii., pp. 304,305 .

37 Riesmans and HekToen : 'Pathology', vol. i., p. 426.

38 to 42 JewETT: 'Practice of Obstetrics,' p. 313 and Plates XIII ., XIV.

$43^{\text {to }} 45$ Thома : 'Text-book of General Pathology,' pp. $184,185$.

The following Works might be consulted:

Hirst and Piersol: 'Atlas of Human Monstrosities.'

BALlantYne: 'Diseases and Deformities of the Fœtus.'

Foerster : 'Die Missbildungen des Menschen.'

AHLFELD : 'Die Missbildungen des Menschen.' 